\title{
FORMULATION OF PEGAGAN FLOUR (Centella asiatica L) AND RED DRAGON FRUIT (Hylocereus polyrhizus) AS CEREAL MILK INGREDIENTS FOR PATIENTS WITH TYPE 2 DIABETES MELLITUS
}

\author{
Ginanda Shofa Naura, Maryam Razak, I Komang Suwita \\ Departmen of Nutrition, School of Health Polytechnics, \\ Ministry of Health Malang, East Java
}

\begin{abstract}
Background: Blood glucose level can be controlled by chemical drugs and medicinal plants. Pegagan (Centella Asiatica L) and Dragon fruit (Hylocereus polyrhizus) are medicinal plants reported to have a potential as an anti-diabetic agent. This study aimed to examine the formulation of pegagan flour (Centella Asiatica $L$ ) and red dragon fruit (Hylocereus Polyrhizus) as cereal milk ingredients for patients with type 2 diabetes mellitus.

Subjects and Method: This was an experimental study conducted from December 2018 to April 2019 at several laboratories including: (1) School of Health Polytechnics laboratory, Malang; (2) Quality and Food Safety Testing laboratory, Universitas Brawijaya, Malang; and (3) BALITKABI central laboratory of Malang. The formulations (in \%) of 3 different ingredients, i.e. pegagan flour, red dragon fruit, and rice flour, were as followed: 20: 50: 30 (Formula 1); 15: 45: 40 (Formula 2), and 10: 40: 50 (Formula 3). The dependent variables were organoleptic quality (color, aroma, taste, and mouthfeel), chemical quality (water content and ash content), nutritional quality (protein content, fat content, carbohydrate content), functional quality (antioxidant and fiber activity), and energy. The independent variable was the concentration formulation of the 3 ingredients. Organoleptic data was analyzed by Kruskal Walis and Mann Whitney. Chemical quality, nutritional, functional, and energy were analyzed by One Way Anova, Duncan multiple range test, and effectiveness index.

Results: There were no differences in terms of organoleptic preference among the 3 formulas, including color $(\mathrm{p}=0.134)$, aroma $(\mathrm{p}=0.418)$, taste $(\mathrm{p}=0.921)$, and mouthfeel $(p=0.743)$. In terms of quality chemical, nutritional, functional, and energy, the best liked formula was formula 1 (20:50: 30). Formula 1 was best liked in terms of water content $(\mathrm{p}=0.033)$, protein $(\mathrm{p}<0.001)$, fat $(\mathrm{p}=0.001)$, carbohydrate $(\mathrm{p}<0.001)$, and energy $(\mathrm{p}=0.001)$.
\end{abstract}

Conclusion: The pegagan flour (20\%), red dragon fruit (50\%), and rice flour (30\%) formula is the best formula of cereal milk for patients with type 2 diabetes mellitus.

Keywords: type 2 Diabetes Mellitus, cereal milk, pegagan, dragon fruit

\section{Correspondence:}

Maryam Razak. Departmen of Nutrition, School of Health Polytechnics, Ministry of Health Malang, East Java. Email: maryamrazako811.gmail.com. Mobile: o81333196137. 